\title{
THE CHIGGER-MITES AFFECTING MAN AND DOMESTIC ANIMALS .
}

By H. E. Ewing and Albert Hartzeld, Ames, Iowa

Although the chigger-mites are widely known over the world on account of their attacks on man and domestic animals, yet, because of their minute size, they have been remarkably exempt from thorough investigations which usually have been applied to pests of so much economic importance. In Europe, due chiefly to the work of Dr. Oudemans and to Berlese, we have recently learned much of the taxonomy, biology, habits, and distribution of the foreign chiggermites.

As is well known among entomologists, chigger-mites are the larvæ of the brilliantly colored harvest mites, which, according to acarologists, are placed in the family Trombidid se. This fact, however, was not known when many of our common chiggers were first described, or if known was not heeded. When these early descriptions were made, the larval characters of real taxonomic importance had not been worked out, so that these descriptions have proved to be all but valueless to us today, notwithstanding we now have an excellent key to the chiggers based on larval characters.

In this paper it has been the object of the writers to give a summary of the important biological and other facts concerning the chiggermites known to affect man and domestic animals, together with references to a few important species found in this country which so far have not been recorded from these hosts. To the recorded observations of others we will add what we have learned of our American chiggers. Some of the species here mentioned have not been suffciently known in the past to have acquired common or popular names, hence one of our chief tasks has been to get appropriate common names for these less known chigger-mites.

\section{The Summer Chigger of Europe}

[Metathrombium poriceps (Oudemans)] (Fig. 10a)

Chigger-mites have been studied more in Europe than in America, and it is now known that at least three different species are concerned in the attacks upon man and domestic animals. Of these three species, two are quite common, one attacking in the summer time, the other in the fall.

The summer chigger-mite of Europe is a very small creature not more than $0.4 \mathrm{~mm}$. in length when unengorged. It is egg-shaped, and has above on the thorax two porous chitinous plates or shields. 

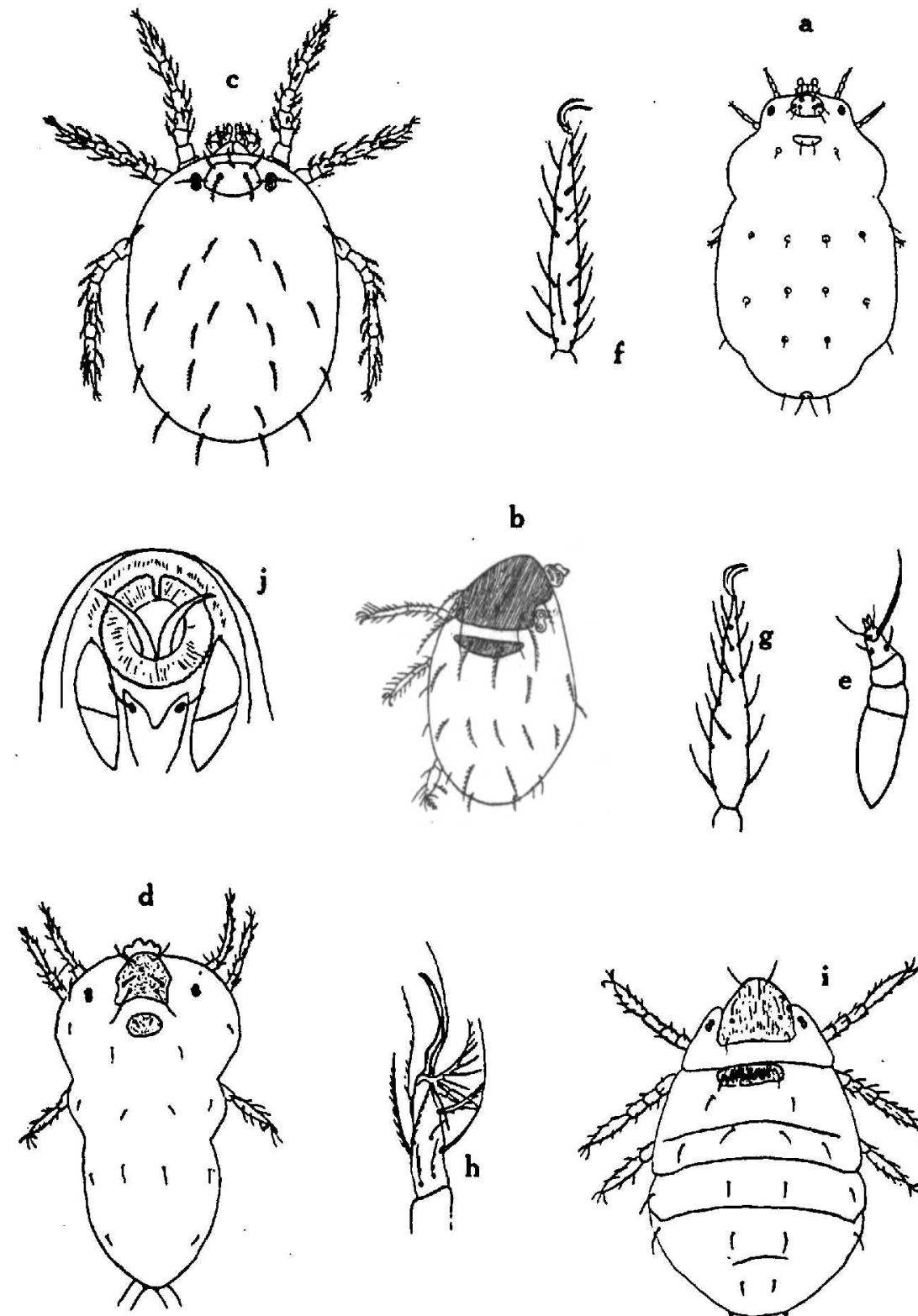

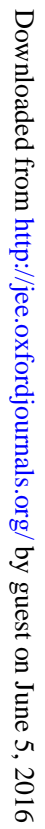

Fig. 10. Some of the more important chigger-mites. A, Metathrombidium poriceps (Oudemans), dorsal view; $b$, Thrombidium striaticeps Oudemans, dorsal view; $c$, Microthrombidium tlalzahuatl (Murray), dorsal view; $d$, Euthrombidium trigonum Hermann, dorsal view; $e$, right palpus from above; $f$, tarsus I of left leg; $g$, tarsus II of left leg; $h$, tarsus III of right leg; $i$, Thrombidium muscarum Riley, dorsal view; $j$, ventral view of mouth-parts. Figures $a, b, c$, and $d$ after Oudemans. Remaining figures drawn from nature by Hartzell. 
This chigger has been frequently reported from man. It also has been taken from the dog, and from chickens. Among the invertebrate hosts we find the house-fly (Musca domestica), many small dipterous insects as well as insects belonging to the following orders: Orthoptera, Ryhnchota, Diptera, Coleoptera, Lepidoptera and Hymenoptera. It has been recorded from spiders, from rodents, and from various mammals. This mite has been collected during the months of June, July, August and September. It is found in the Netherlands, France and Germany; and doubtless occurs in other parts of Europe.

\section{The European Autumanal Chigger}

[Microthrombidium pusillum Hermann]

It is the autumnal chigger-mite that has become noted because of its attacks on man and beast in Europe. This chigger-mite was long known under the name of Leptus autumnalis, and gave rise to a severe rash or itch which was called "erythema autumnale."

When unengorged these chiggers are very minute, being scarcely visible to the naked eye. They are brick red in color, and have above one dorsal median shield, which is trapezoidal in shape.

It was for a long while believed that this mite, as well as chiggers generally, lived on the juices of plants and that only under certain conditions did it become blood thirsty. C. V. Riley shared this belief with others, and stated as follows in regard to one of our American chiggers: "I have stated my belief that its normal food must, apparently, consist of the juices of plants and that 'the love of blood proves ruinous to those individuals who get a chance to indulge it." "

The belief that chigger-mites lived normally on the juices of plants gained credence no doubt largely on account of Claparede's contention that they belonged to Tetranychus, a genus composed of plantfeeding acarids.

This chigger, like all other species of its genus, lives normally upon invertebrate hosts, especially insects, and is an accidental parasite only on higher animals. Besides being especially severe when on man, it is troublesome to horses, cattle, sheep, rabbits, dogs, and cats. When first attacking they attach themselves by means of their claws and palpi. Around the attached chigger, swellings are said to develop which may be as large as a pea or larger, and there is severe itching. It has been stated that fevers result at times after mite attacks, hence it is believed by some that this species, as well as others, gives off a toxin. This chigger has been reported for the months of September, October, and November.

Various insects are reported as being hosts for this mite, and are probably the normal ones. Among the other hosts reported are dif- 
ferent birds and mammals. Oudemans has compiled a list of fourteen determined host species. To this should be added a larger list of hosts that were only determined to the genus or family. The species is reported from England, France, Belgium, Holland, and Germany.

\section{The Striated European Chigger}

\section{[Thrombidium striaticeps Oudemans] (Fig. 10b)}

There is another chigger-mite of Europe known to attack man and domestic animals. It does not appear to be as common or as important a pest as the two just considered. This chigger has parallel striations on the dorsal shields or plates. The larvæ are egg-shaped, and when somewhat swollen with blood are about $0.5 \mathrm{~mm}$. in length.

This chigger has been found on man, the dog, the cat, and the domestic fowl. Its normal hosts are for the most part dipterous species. It has been reported from France, Belgium, and Holland.

\section{The Kedani Mite}

\section{[Microthrombidium sp.]}

In certain parts of Japan there is a chigger-mite that has been associated with a fatal disease known as river fever or flood fever. Tanaka, especially, insists that there is a connection between these mites and this disease. It appears that the mites by their attacks produce lesions which become points of entrance for certain bacteria which are the real cause of the fever. At the point of attack there is a papule which becomes surrounded by an inflamed area. This is followed by a pustule which gives way to a black scab.

The mites concerned are orange-red, and measure about $0.2 \mathrm{~mm}$. in length when not engorged. The palpi are strong and single clawed. The legs are stout, and each is provided with three tarsal claws, the middle one being longer than the rest. The femora are divided. Above, the body is clothed with about thirty long doubly pectinate hairs.

The kedani mite appears to be a Microthrombidium species according to Tanaka's figure. Yet he does not show some of the more important taxonomic characters. The adult form is unknown.

\section{The Ceram Chigger}

\section{[Microthrombidium wichmanni (Oudemans)]}

Two chigger-mites are found in the East Indies that according to the various but authentic reports of different travelers must cause a scourge which is far more severe than any caused by the species of the temperate zones. One of these mites, it appears, is the species 
which Wallace mentions in his work on the Malay Archipelago as causing him to come down with a serious disease while on his first visit to Ceram. For this reason we shall call this species the Ceram chigger.

In this species there is a single median shield present without crista. There is only one pair of psudostigmata. The tarsi have two thick and one thinner and longer claw. Two eyes are present.

Oudemans states that this species was collected in New Guinea in separate lots on the head of Goura sp., where they had fastened themselves to the skin by the hundreds in regular rows, like paving stones. They had caused the feathers to fall from the infested region.

Alfred Russel Wallace gives his experiences with a species in Ceram which it appears is the one under consideration. He states: "All the time I had been in Ceram I had suffered much from the irritating bites of an invisible acarus, which is worse than mosquitoes, ants and every other pest, because it is impossible to guard against them. This last journey in the forest left me covered from head to foot with inflamed lumps, which after my return to Amboyna, produced a serious disease, confining me to the house for nearly two months."

Besides being found on man, this chigger has been recorded from Goura coronata. Authentic records of the species are from New Guinea and the Celebes. In addition we have Wallace's report from Ceram which probably concerns this species.

\section{The East Indian Shrub Chigger}

[Schöngastia vandersandei (Oudemans)]

In this country the chigger-mites are found almost entirely in the grass, even short grass at times harboring them. In New Guinea there is a chigger that climbs shrubs and bushes where it is brushed upon the bodies of larger animals as they pass by.

It is a bright red chigger with a single, trapezoidal, dorsal shield. The coxæ each have one hair. The dorsal shield is convex behind; palpal claws two or three partate. Mandibles claw-like, long, straight and toothed.

This species causes a disease known in New Guinea as shrub-itch. Wayfarers brush the almost invisible mites onto their bodies from the low hanging branches of trees or from shrubs. The mites are said to get under the skin, and to cause a terrible irritation. Besides occurring on man, the shrub-chigger has been found on Goura coronata. It is common in New Guinea, and probably occurs in neighboring islands. 


\section{The Mexican Chigger-Mite}

\section{[Microthrombidium tlalzahuatl (Murray)] (Fig. 10c)}

The Mexican chigger mite has been known to entomologists through our scientific literature for half a century, and due to the efforts of Oudemans we now have most excellent figures of it. This mite was originally described by Murray in his well-known volume on "Economic Entomology-Aptera" although it was mentioned earlier by Lemaire who has given us an account of its accidental introduction into France at an early date.

The larvæ are a bright yellow orange, and the body is oval in shape, being evenly rounded at either end. There is a single shield above; and the rather conspicuous palpi each end in a bifurcate claw.

This mite is said to occur in the more temperate parts of Mexico, and is not found in the hot dry regions. It attacks the eyelids and armpits especially and apparently through predilection. The Indians, it is stated, remove these chiggers by means of a fine grass stalk when a needle is not obtainable.

The natural hosts of the mite have not been determined, and we have no record of it attacking other mammals than man, but it very probably does. Osborn has suggested that this species may be distributed over parts of the Southern States. The chiggers which the senior writer has so often encountered in Mississippi do not attach at the eyelids or armpits, but about the ankles and calves of the legs.

\section{The American Chigger-Mite}

\section{[Genus? Species?]}

We have at least two species of chiggers in the upper Mississippi Valley which attack man. This was shown by no other than C. V. Riley who obtained his original material from the superficial anatomy of one, Otto Lugger,-well-known American entomologist. Riley described one of these species under the name of Leptus americanus and the other under the name of Leptus irritans, and gave figures of each. The figures of Riley's have been copied many times, and are familiar to most of you present at this meeting. It is almost lamentable that from them one can get hardly a character which is used today in specific diagnosis of chigger-mites. As the two mites were not reared we are left in doubt to this day as to their identity.

Riley's Leptus americanus was a very small chigger for he states: "This species is barely visible to the naked eye. . . ." It has a slender body, rounded behind and pointed in front. The legs were very long and slender. Although the present writers have observed many harvest mite larvæ in Iowa, we have failed to find any liable 
to attack man, which look similar to Riley's drawing of his Leptus americanus.

Riley states that this mite infests chiefly the scalp and armpits, that it does not bury itself in the flesh, but simply insinuates the anterior part of its body under the skin. The method of attack given by Riley at once suggests the Mexican chigger, but if you will compare Riley's figure with Oudeman's drawing of the Mexican chigger you can see at once that they are different species. The Mexican chigger is a broad, stout species, with moderate legs, while Riley's drawing of americanus shows the legs longer than the body. We know nothing of the natural hosts of the mite or if its distribution other than that it is found in the upper Mississippi Valley.

\section{The Irritating Chigger-Mite}

\section{[Genus? Species?]}

This species, which has long gone under the name of Leptus irritans Riley, has been most frequently mentioned in our American literature. Riley says of it: "This is the most troublesome and perhaps best known of the two (the other species being his Leptus americanus) causing intense irritation and swelling on all parts of the body. . . ." We have made many attempts to place this species of Riley's but have failed. It can not be placed even in the proper genus, as we recognize the genera of Trombidides today.

The irritating chigger according to Riley's figure and description is of minute size, but has a broad body and very large palpi. Indeed the palpi, as shown in Riley's figure, are larger in proportion to the body than in any of our known species.

Since Riley, as well as others, speaks of this chigger as being so common and so troublesome it may be thought by some that it is no other than our common locust chigger so frequently found on the wings of grasshoppers in the upper Mississippi Valley. This point has been tested here at Ames by letting these. locust chiggers crawl over the bare arms and legs without effect. Individuals have gone through grass heavily infested with these locust chiggers with the trousers rolled up at the bottom and with the socks rolled down at the top, but without a single attachment. Many men have been observed working in areas infested with these chiggers, but they have not complained of being attacked. Just what species Riley's irritans will prove to be we cannot say. It very probably will never be known for a certainty.

\section{The Locust Mite}

[Euthrombidium trigonum (Hermann)] (Fig. 10d, e, $f, g$, and $h$ )

The larvæ of this species were first reported from Omaha, Nebraska, 
by Riley, in 1868, on the Rocky Mountain locust. The following year it was reported from Oregon and Missouri. In May, 1874, the adult was observed attacking the eggs of the Rocky Mountain locust in northwestern Iowa. It was recognized by Riley as Trombidium sericeum Say. At that time the immature stages of the Trombididd $x$ were unknown. In the same report he recognized the larval form, of what afterwards proved to be the same species as the above, as Astoma gryllaria LeBaron. Riley was the first to work out the life-history of the locust mite. In 1878 he published a description of it as a new species under the name Trombidium locustarium. Banks, however, considers it a synonymn of Astoma locustarium Walsh. In 1912 the senior writer sent an adult locust mite to Berlese, who determined it as Euthrombidium locustarium Walsh. A larva of the same species, taken from Melanoplus differentalis, was sent to Dr. Oudemans, who recognized it as nothing less than the European Euthrombidium trigonum Hermann. Since Oudemans based his determination on larval characters, which in this group are more definite than adult characters, we believe it to be correct. Furthermore, we have carefully compared Oudeman's and Berlese's descriptions and figures with our own material of this species and conclude that Euthrombidium locustarium Walsh is synonymous with Euthrombidium trigonum Hermann.

The larvæ of the locust mite may be distinguished from the other members of the genus by the bifurcate coxal spurs and the four hyaline lobes on the cephalic border of the front dorsal shield.

Riley was first to study the biology of this species. The senior writer has also carried on life-history experiments with this mite, and succeeded in rearing an adult from a larva infesting Melanoplus bivittatus. The adults showed a decided preference for grasshopper eggs. In no case could the mites be induced to attach themselves to man. It is also of interest to note that this mite has never been reported from man or domestic animals in Europe.

As far as is known the hosts of the locust mite are confined to four families of Orthoptera, namely: ACrididde, Locustide, Gryluid a and Mantides. It has been found on the following species of grasshoppers in this country: Melanoplus differentialis, M. spretus, $\boldsymbol{M}$. augustipennis, Spharagemon bolli, Schistocerca americana.

Euthrombidium trigonum is generally distributed throughout Minnesota, South Dakota, Iowa and Illinois. It has been reported from Nebraska, Kansas, Missouri and Oregon. It has also been found in Germany and Holland. 


\section{The House-fly Chigger}

\section{[Thrombidium muscarum Riley] (Fig. $10 i, j$ )}

The larvae of this species were recognized by Riley, in 1875, as Astoma parasiticum Latreille. Two years later a description of it was published in the Report of the United States Entomological Commission as a new species under the name Trombidium muscarum Riley. We have carefully examined the larva of his form and believe that the species is valid, and should be retained in the genus Thrombidium. This genus may be distinguished by the presence of two median dorsal shields. The front shield is furnished with eight setæ and has longitudinal striations.

During some seasons scarcely a house-fly can be found that is not infested with a number of these mites. Riley succeeded in rearing the adult. The senior writer has also reared the adult of this species.

As far as known this mite is confined to a single host, Musca domestica. It could never be induced to attach to man. Apparently this chigger is generally distributed throughout the United States. We have records from New York, Illinois and Iowa.

\section{SUMMARY}

1. Six separate and distinct species of chigger-mites taken from man and domestic animals have been accurately described, figured and named. Three of these are found in Europe, two in the East Indies and one in Mexico.

2. At least two distinct chigger-mites are known to attack man in this country. We have been unable to place either one of these species in our modern classification of the chigger-mites, and are in doubt in regard to their specific identity.

3. The common locust mite in the United States is the same as the common locust mite of Europe, hence Trombidium locustarium Walsh is a synonym of Euthrombidium trigonum (Hermann) of the old world. Observations and experiments have shown that this species does not attack man.

4. The scientific name of our house-fly chigger, Thrombidium muscarum Riley, still stands, the species being good.

5. Only two species of our American chigger-mites have been reared to maturity.

6. A thorough survey of our chigger-mite fauna, with notes on hosts and geographical distribution is most needed at present. 